ISSN 1112-9867

Available online at

http://www.jfas.info

\title{
DENSITY AND DRY WEIGHT OF PIGWEED BY VARIOUS WEED CONTROL METHODS AND VARIOUS RESOURCES OF NITROGEN FERTILIZER IN CORN FORAGE FARM
}

M. Aryan Mehr ${ }^{1}$, A. Ghanbari ${ }^{2}$, R. Ghorbani ${ }^{2}$, M. Nasiri Mahallati ${ }^{2}$, R. Khorasani ${ }^{2}$, G. Asadi $^{2}$

${ }^{1} \mathrm{Ph}$.D. student of weed sciences field, Ferdowsi Mashhad University

${ }^{2}$ Faculty member of Ferdowsi Mashhad University

Published online: 15 May 2016

\begin{abstract}
This study evaluates effects of various weeds control methods and nitrogen fertilizer resources on density and dry weight of pigweed and the performance of corn forage as factorial in full random block design with 3 repetitions in research farm of Ferdowsi Mashhad University in 2014. The test treatments include weed control methods such as chemical control, compound (mechanical+ chemical) control, and no control and types of nitrogen fertilizer including (urea, sulfate ammonium, nitrate calcium, nitrate ammonium, and nonusing fertilizer). Density and dry weight of pigweed was measured four times in growing season to determine changes procedure. In the Corn primary stage, the performance of wet forage was also measured. The obtained results from test showed that forage performance at the end of growing season, and density and dry weight of pigweed after 60 days of planting were significantly influenced by control methods, type of nitrogen fertilizer, and interaction of control methods and type of nitrogen fertilizer. $(\mathrm{P}>0.01)$ the highest forage performance was obtained in compound control method and nitrate calcium fertilizer treatment with approximate weight of $12072 \mathrm{~kg} / \mathrm{hec}$.
\end{abstract}

Author Correspondence, e-mail: m.arianmehr@um.ac.ir

doi: http://dx.doi.org/10.4314/jfas.v8i3s.249 
In no control and studied fertilizers treatment in test, the pigweed density has stayed constant with soft descending slope 20 days after planting so on, and its weight increased until 60 days of planting and then decreased until the growing season.

Keywords: Compound Control, Nitrogen Fertilizer Resource, Pigweed, Corn Forage

\section{INTRODUCTION}

Weeds are one of the most important reducers of agricultural plants performance and the problems that farmers face with it annually (Jahad Akbar et al., 2004; Kuchaki wet al., 2001) the management of weeds is mostly one of key elements in agricultural systems (Evans et al., 2003). 250 plant species have been introduced as weeds and $70 \%$ and $30 \%$ includes the wide leaf and narrow leaf varieties, respectively. (Jahad Akbar et al., 2004) the competitiveness of weeds reduces agricultural productions $10 \%$ in average, and the agricultural plants performance in dependent on their competitive potential reduces 10 to $100 \%$ without control them (Kropff et al., 1993). The corn is four-carbon plant that has been extensively used for live stocks feeding for its high potential of producing seeds and forage in Iran, and its agriculture has been developed in most provinces of country. Studies show that 2-30 problematic weeds grow in farms including yearly and several year ones (Vafabakhsh, 1995). Although, corn in spite of other agricultural plants is not a weak plant against weeds, there is emergent need to control weeds. Vazin (2006) reported that corn in its initial growing steps is sensitive to weeds, particularly the wide leaf ones.

The weeds in reduces corns performance this step by delaying growth and reducing corn competitive potential. In addition, weeds make many problems in forage corns in cultivation and deterioration the straw in forage or storage tank. The losses made by weeds on corns are different according to density, species composition, relative greening time, climate, agricultural cultivars, and other factors. Kuchaki et al. (1997) and Vafabakhsh (1995) stated that non-control weeds depending on density and varieties of weeds, the corn performance may reduce 15 to $90 \%$ if weeds are not controlled. The most important weeds for corn in Iran is pigweed, Amaranthus retroflexus L., Chenopodium album L, Abutilon theophrasti Medik, Convolvulus arvensis Physalis alkekengi, Sorghum halepense (L.) Pers, Echinochloa 
crusCyperus rotundus -galli L. (L.) P. Beauv. Digitaria sanguinalis L, and Setaria spp. (Mousavi, 2001). The red pigweed called Amaranthus retroflexus L. is one of the most important weeds that damage agricultural plants in extensive parts of the world (Aguyoh and Masiunas, 2003). Results of an experiment in |Mashhad wheat farms showed that wide leaf one-year plants constitutes the main compositions of seeds bank of all studied soils, and Purtulaca oleracea, Chenopodium album L, and pigweed species were dominant (Koocheki and Nassiri, 2005). The Amaranthus retroflexus L. has high growth and seed producing rate (Mitich, 1997) and has high power in high thermal conditions, low humidity, and low light for short-day growth type and four-carbon photosynthesis system (Guo and Al-Khatib, 2003).

One of the most important methods of control weed in the world and Iran is chemical control (Zand et al., 2007). Nicosulfuron (Cruse ${ }^{(\mathrm{R})}$ ) is new and double-purpose herbicide from sulfonyl Urea family and is belonged to Group B or 2 preventing ALS ${ }^{11}$ enzyme. Nicosulfuron is used post-growing with 17.5-70 effective amount in hectar in mixed or pure form mainly to control wide leaf weeds in corn farms. (Sensmen, 2007)

Using herbicides is valuable in control weeds, but in using them as weed management, they will worth more. In other words, it had better use herbicides as a part of a designed system to minimize the related losses to weeds in total production system chronically. In this case, using herbicides in the texture of weeds management helps to obtain another important purpose. For example, using herbicides to cease weeds growth instead of removing them can prevent from soil corruption. (Rashed Mohassel and Mousavi, 2007)

The result of agricultural pant and weeds interruption depends on appropriate factors to location, particularly the essential nutrition (DiTomoso, 1995). Therefore, the nutritional elements management is known as probable technique for weed management (Walker and Buchanan, 1982). Since two third parts of |Iran is dry and semi-dry climate, the organic materials in soil are low, and it is necessary to provide the soil needed nitrogen by chemical and organic fertilizers (Malakuti and Reiyazi Hamedani, 1991). Nitrogen is an important and vital element for plant growth and is used in making proteins, nucleic acids, and chlorophyll. This element is losing more than other nutrition materials and its recycle amount is less than half (Boswell et al., 1985). Agricultural plants and weeds need to similar nutrition (Nieto and 
Staniforth, 1961). Many studies have shown that weeds absorb more mineral materials in comparison to agricultural plants and reduce soil fertilization, so eventually reduce agricultural plants performance (Vengris et al., 1955). Using proper amounts and resources of nitrogen is an important part of nitrogen fertilizers management (Landy et al., 1999)

The effects of various nitrogen fertilizer resources including urea, nitrate ammonium, Sulfate ammonium, nitrate calcium, and weed control methods were studied on procedures of density and dry weight of pigweed and performance of corn forage.

\section{METHODOLOGY}

This research was conducted in agricultural research farm of Ferdowsi Mashhad University with $35^{\circ}$ latitude and 15 min north, and 59 longitude and 28 in east in $985 \mathrm{~m}$ altitude.

This research was the factorial test in full random block designs with 3 replications. Test treatments include weeds control methods such as chemical control, combined control, and control group without control, and the used nitrogen fertilizer includes urea, sulfate ammonium, nitrate calcium, nitrate ammonium, and control group without fertilizer. The spraying was done in 5-7 leaf step with double-purpose herbicide nicosulfuron with $2 \mathrm{l} / \mathrm{h}$ dose. Spaying was done by alternative pressure backpack sprayer two times. The sprayer was calibrated for 300 1/hec output flow. For combined control, besides spraying by nicosulfuron herbicide as it was one in chemical control method, the weed mechanical control was done manually be help $\mathrm{f}$ shovel. The Nicosulfuron herbicide was a selected and systematic herbicide from sulphonyl urea group with suspension formula (Sc4\%) and low toxicity degree for mammals (LD50> 5000mg/kg) to control one-year or multi-year thin-leaf and wide-leaf weeds which were recorded and recommended on farms.

After land preparing operations including disc, plow, and leveler, and determination the range of blocks and plots, corn, single-cross cultivar was cultivated by 6 series pneumatic seeder in June, 10, 2014. Each plot dimension was $6 * 3$ and 4 cultivation series was considered for each plot. The distance of series was $75 \mathrm{~cm}$ and distance of bushes in series was considered $10 \mathrm{~cm}$ after distribution. The first irrigation was done 3 days after cultivation, then irrigation was done once every 7 days. 
To test soil before cultivation, samples were collected from 10 points of the tested land from 0-30 cm depth, and soil was tested after their mixing. Results of analyzing test samples are shown in table (1).

Table 1. Results of soil samples testing

\begin{tabular}{|c|c|c|c|c|c|c|c|c|c|c|}
\hline $\begin{array}{l}\text { Soil } \\
\text { texture }\end{array}$ & $\begin{array}{l}\text { Clay } \\
\%\end{array}$ & $\begin{array}{l}\text { Silt } \\
\%\end{array}$ & $\begin{array}{l}\text { Sand } \\
\%\end{array}$ & $\begin{array}{l}\text { Total } \\
\text { nitrogen } \\
\text { (P.P.M) }\end{array}$ & $\begin{array}{l}\text { Absorbable } \\
\text { potassium } \\
\text { (P.P.M) }\end{array}$ & $\begin{array}{l}\text { Absorbable } \\
\text { Phosphorus } \\
\text { (P.P.M) }\end{array}$ & $\begin{array}{l}\text { Organic } \\
\text { carbon } \\
(\%) \text { O.C }\end{array}$ & $\begin{array}{l}\text { Percentage } \\
\text { of neutral } \\
\text { materials } \\
\text { T.N.V }\end{array}$ & $\begin{array}{l}\text { Saturati } \\
\text { on Soil } \\
\text { acidity } \\
\text { pH }\end{array}$ & $\begin{array}{l}\text { Electrically } \\
\text { conductive } \\
\text { Ec(ds/m) }\end{array}$ \\
\hline $\begin{array}{l}\text { Silty } \\
\text { loam }\end{array}$ & 6.37 & 52.45 & 41.18 & 680 & 186 & 18.6 & 0.78 & 1.34 & 7.85 & 915 \\
\hline
\end{tabular}

Triple super phosphate fertilizer $46 \%$ and sulfate potassium $50 \%$ were mixed similarly before cultivating by $80 \mathrm{~kg} / \mathrm{hec}$ and $120 \mathrm{~kg} / \mathrm{hec}$, respectively. The studied fertilizers in this study include urea, sulfate ammonium, nitrate calcium, and nitrate ammonium with 260, 570, 775, and $400 \mathrm{~kg} / \mathrm{hec}$, respectively. The nitrogen percentage in these fertilizers was 46, 21, 15.5, and $30 \%$, respectively. These fertilizers were used in three steps. One third while cultivation, one third as newly grown plant fertilizer (25 days after cultivation, the 4-6 leaf step of corn), and one third is used when seeing lack of nitrogen on corn plant (55 days after cultivation, 10-12 leaf step). During growth 4 steps (20, 40, 60, and 90 days after corn cultivation), the density and dry weight of pigweed was measured in various treatments. As a constant frame inn $0.5^{*} 0.5 \mathrm{~m}$ was installed in each plot and number of pigweed bushes were counted in 4 growth steps. The non-constant frame was used to measure dry weight of pigweed bushes. In order to determine effect of test treatments on the produced dry materials by pigweed, a $0.5 * 0.5 \mathrm{~m}$ frame was installed in a way that was thrown randomly in each plot, and pigweeds bushes were filled by surface soil inside frames and put in $72^{\circ} \mathrm{C}$ oven for $48 \mathrm{~h}$. Then, their dry weights were obtained by measuring on digital scale. Changes procedures of pigweed density and dry weight in nitrogen fertilizer treatments and weed control methods of pigweed were fitted by Sigma Plot-ver 12.5 in normal thee-parametric log (equation 1). The weed control methods effect was also fitted on pigweed density and dry weight in two-parametric potentially decreasing function and three-parametric normal log (equation 1). For better data fitting, the density of weed for the first date of cultivation was considered zero and pigweed seed weight 
that was greened in the next step was considered as weed weight in the first day after cultivation. The obtained data from testing was variance analyzed using SAS statistical software, and related mean data was compared using Duncan multi-range test in 5\% level by interaction of control methods and nitrogen fertilizer type o performance at the end of growth season, density, and dry weight of pigweed in 40 and 60 days after cultivation. In order to increase accuracy in comparison pigweeds mean density and dry weights the interaction cutting of control methods was done in each fertilizer after 40 And 60 days of corn cultivation day, and significance of each surface was compared to its error level instead of total error variance.

\section{FINDINGS}

\section{The Changes Procedure of Density and Dry Weight of Pigweed Plant in Chemical}

\section{Control Method}

The dominant changing procedures of pigweed density and dry weight are shown in chemical method and 5 types of nitrogen fertilizers in figure (1) and (2), respectively. As it is observed in figure (1), density of pigweed has reduced with higher slope in $20^{\text {th }}-40^{\text {th }}$ day of cultivation. Wince the plant was sprayed in $23^{\text {rd }}$ day after cultivation, this density reduction shows good efficiency of Nicosulfuron herbicide on control number of pigweeds.

The related curves to pigweed density in various nitrogen fertilizer resources are near to each other after $20^{\text {th }}$ days of cultivation while the related curves to pigweed dry weight in nitrate calcium and nitrate ammonium is significantly higher than the related curves to pigweed dry weight in urea, sulfate ammonium, and treatment without fertilizer. In comparison of related curves to dry weight and density inn chemical control treatment, it is speculated that nitrogen calcium and nitrate ammonium treatments didn't have significant effect on number of weeds in spite of other fertilizers, but the incremental effect of these two fertilizers than other studied fertilizers is significant. This reason is for probable better usage of pigweed from nitrate calcium and nitrate ammonium.

The Changes Procedure of Density and Dry Weight of Pigweed Plant in Combined Control Method 
The changes procedures of density and dry weight of pigweed in combined (chemical +mechanical) method and five nitrogen fertilizers in this test are shown in figures (3) and (4). In spite of the used fertilizer, the pigweed density after $20^{\text {th }}$ day of cultivation showed decremented procedure, and density get to zero nearly the $60^{\text {th }}$ day of cultivation. The density of weeds doesn't show different under various fertilizers. This may be probably for spraying and mechanical control of weeds that damaged pigweeds and the remained number of them was failed in competition with corn plants. The changes procedure of pigweed dry weight in combined method treatment is similar to its density procedure.

\section{The Changes Procedure of Density and Dry Weight of Pigweed Plant in Non-Control}

\section{Method}

The changes procedures of density and dry weight of pigweed in non-control method and five nitrogen fertilizers in this test are shown in figures (5) and (6). Figure (5) shows that nitrate calcium and nitrate ammonium fertilizer treatment of pigweed after $200^{\text {th }}$ day of cultivation had incremental procedure and then constant. In sulfate ammonium, urea, and non-using fertilizer treatments, the pigweed density since $20^{\text {th }}$ days of cultivation to the end of growing season had decremented procedure. It is also seen in figure (6) that the maximum weight of pigweed was obtained nearly $60^{\text {th }}$ day after cultivation in calcium nitrate fertilizer that shows significant difference in pigweed dry weight in non-using fertilizer treatment. According to figure (6), other fertilizers also increase pigweed dry weight than non-using fertilizer treatment. However, thee significant pigweed dry weight increase intensifies the necessity of more précised study to increase this weed dry weight in nitrate calcium than other studied fertilizers.

\section{Comparing Density and Dry Weight of Pigweed in Various Control Methods}

Changes in density and dry weight of pigweed in these treatments are shown in figure (7) and (8).

As it is seen in figure (7), density and dry weight has decremented procedure in chemical and combined methods as though density and dry weight at the end of growth season reaches to zero. In non-control treatment, the pigweed density had decremented procedure with soft slope of 0.005 . Pigweed weight in non-control method had significant increase after the $20^{\text {th }}$ 
day of cultivation, and this increase continued nearly to $60^{\text {th }}$ day, then it reduced. Although, the pigweed plant density was constant ingrowth season in non-control treatment, the significant increase of dry weight showed pigweed ability in using resources and competitiveness with corn. It can be suggested that the method of increasing single-bush weight than increasing number of small bushes is recommended in pigweed competitive condition to increase competitiveness for corn in accessing to light in presence of shadowing rival.
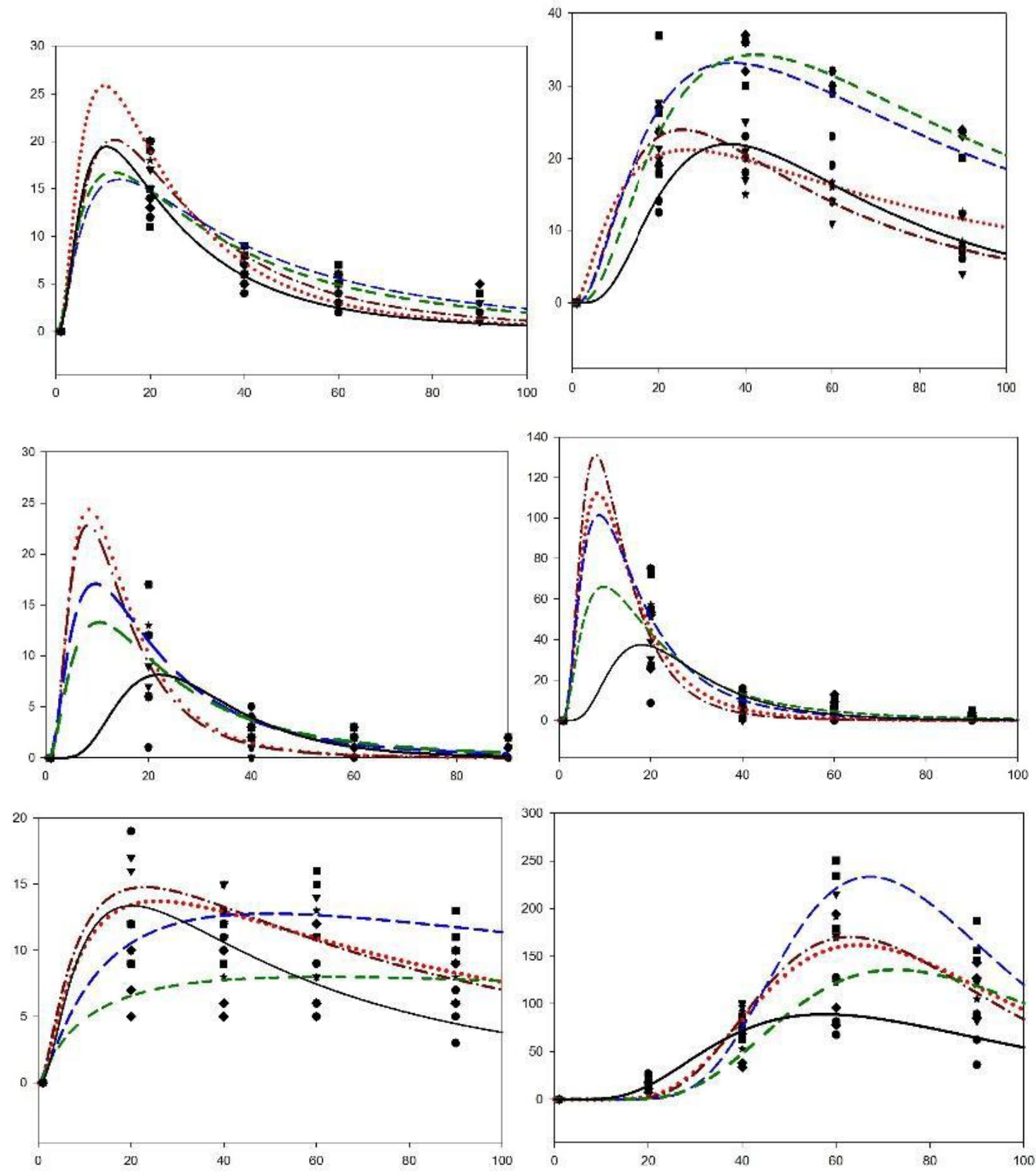

Days after cultivation 


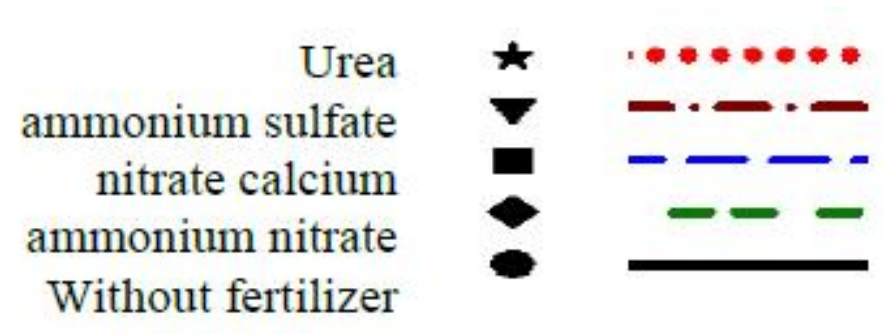

Functions equation:

$$
\mathrm{f}=\operatorname{if}\left(\mathrm{x}<=0,0, \mathrm{a}^{*} \exp \left(-0.5^{*}(\ln (\mathrm{x} / \mathrm{x} 0) / \mathrm{b})^{\wedge} 2\right) / \mathrm{x}\right)
$$

Fig.1. pigweed density in chemical control treatment (number of bushes in $2500 \mathrm{~cm}^{2}$ )

Fig.2. pigweed dry weight in chemical control treatment (number of bushes in $2500 \mathrm{~cm}^{2}$ )

Fig.3. pigweed density in combined control treatment (number of bushes in $2500 \mathrm{~cm}^{2}$ )

Fig.4. pigweed dry weight in combined control treatment (number of bushes in $2500 \mathrm{~cm}^{2}$ )

Fig.5. pigweed density in non-control treatment (number of bushes in $2500 \mathrm{~cm}^{2}$ )

Fig.6. pigweed dry weight in non-control treatment (number of bushes in $2500 \mathrm{~cm}^{2}$ )

Figure (1) and (2) show the changes procedures of density and dry weight of pigweed in growth season by chemical method

Figure (3) and (4) show the changes procedures of density and dry weight of pigweed in growth season by combined (chemical +mechanical) method

Figure (5) and (6) show the changes procedures of density and dry weight of pigweed in growth season by non-control method
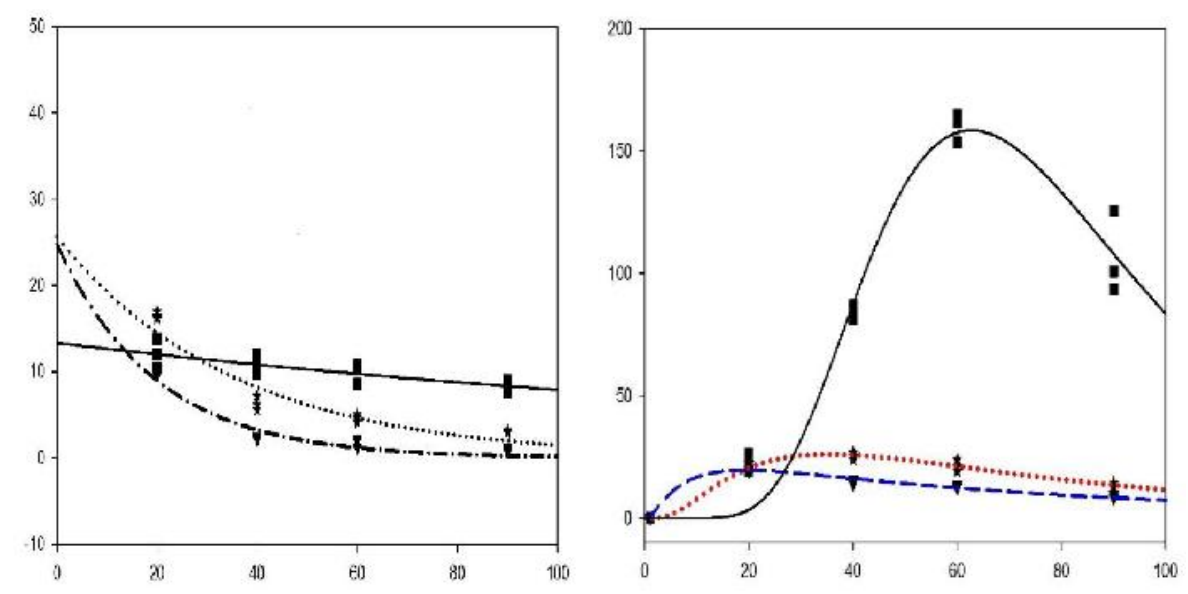

Days after cultivation

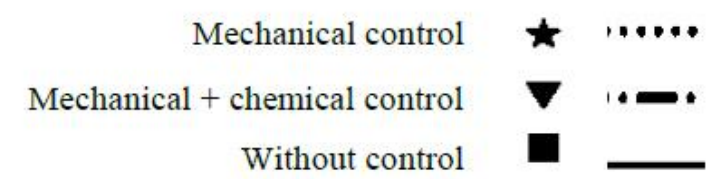


Fig.7. pigweed density in various control methods (number of bushes in $2500 \mathrm{~cm}^{2}$ )

Fig.8. pigweed dry weight in various control methods (number of bushes in $2500 \mathrm{~cm}^{2}$ )

Function equation in figure (7): ${ }^{\mathrm{f}-\mathrm{if}\left(\mathrm{x}<-0,0, \mathrm{a}^{*} \exp \left(-0.5 *\left(\ln (\mathrm{x} / \mathrm{x}(0) / \mathrm{b})^{\wedge} 2\right) / \mathrm{x}\right)\right.}$

Function equation in figure (8): $f=a * \exp (-b * x)$

Figure (7) and (8) show the changes procedures of density and dry weight of pigweed in growth season by various control methods during time

\section{Pigweed Density and Dry Weight after 40 Days of Cultivation}

According to variance analysis results, the pigweed control method has significant effect on its density in 40 days after cultivation in $1 \%$ probability level. In addition, control and interaction methods and type of nitrogen fertilizers showed significant effect on pigweed dry weight after 40 days of cultivation in $1 \%$ probability level. The main effect of control methods on pigweed density and dry weight showed that the traits in chemical and combined method didn't have significant difference. The maximum density and dry weight of pigweed in noncontrol method was $61 \%$ and $76 \%$, respectively more than two other methods (Table (2)). The pigweed dry weight wasn't influenced by fertilizer treatments (Table 3).

The comparison between density and dry weight of pigweed after 40 days of cultivation under interaction of control methods and type of nitrogen fertilizers are shown in figures (9) and (10), according to figure (9), no significant difference was seen in type of nitrogen fertilizers and chemical and combined control methods according to weed density (by density mean 21.33 and 18.66 bushes in $\mathrm{m}^{2}$ for chemical and combined control treatments, respectively). Although, thee wed density in chemical and combined control treatments didn't show significant difference in all type of nitrogen fertilizers (figure (9)), comparison thee mean dry weight of pigweed dry weight has significant difference between these two treatment. This is in spite of the non-using fertilizer method that pigweed dry weight was more in combined treatment than chemical treatment. In all urea fertilizers, sulfate ammonium, nitrate calcium, and nitrate ammonium, the pigweed dry weight in chemical control treatment was obtained $65 \%, 68 \%, 61 \%$, and $71 \%$ more than combined control method. (Figure (10)) 


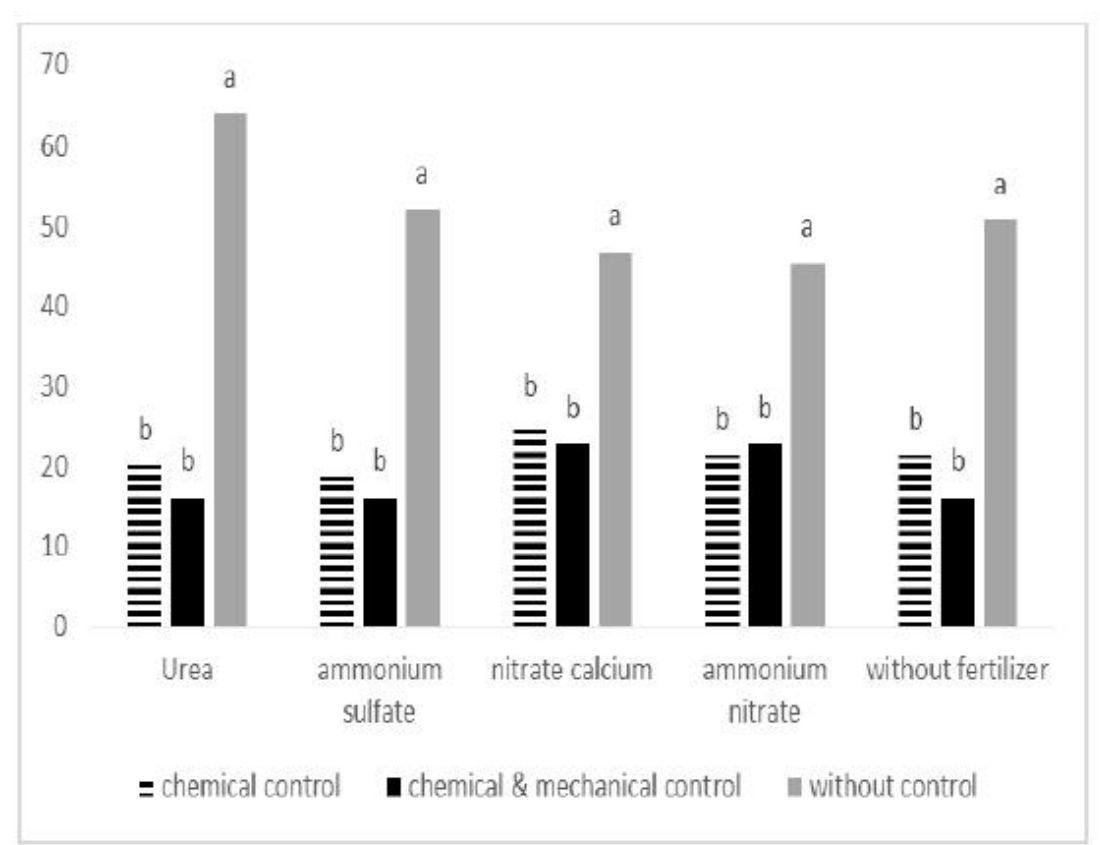

Fig.9. the interaction of fertilizer type and control method on pigweed density means (bushes in per $\mathrm{m}^{2}$ ) 40 days after cultivation

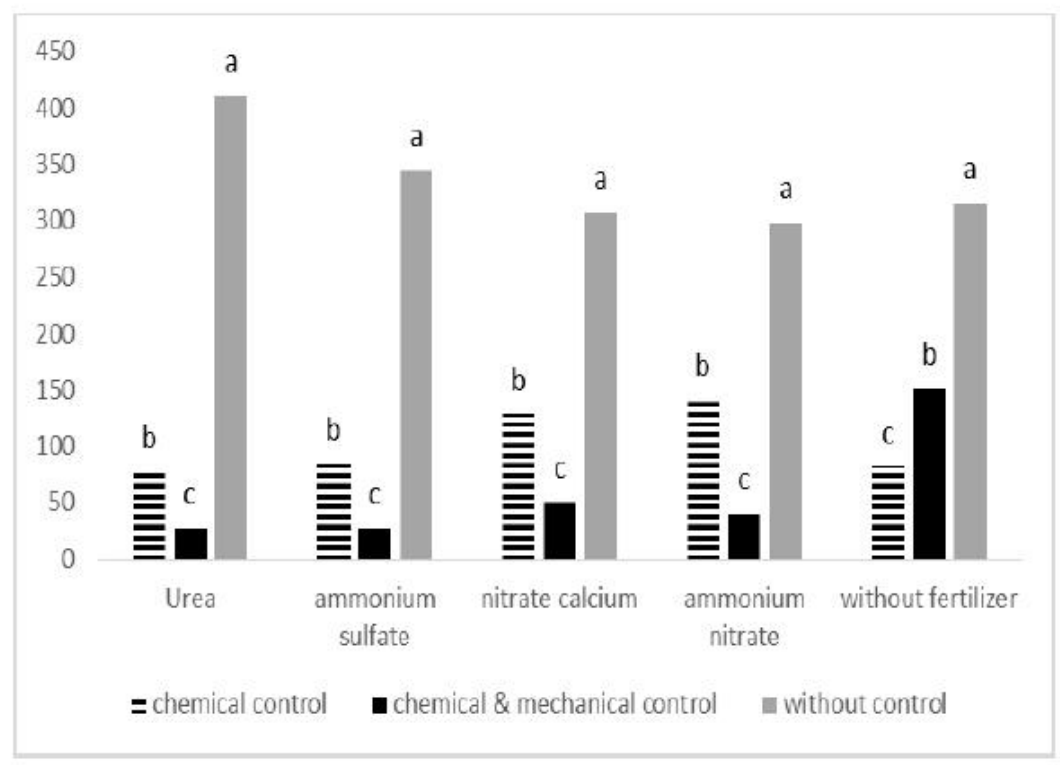

Fig.10. the interactions of fertilizer type and control method on pigweed dry weight mean (bushes in per $\mathrm{m}^{2}$ ) 40 days after cultivation

\section{Pigweed Density and Dry Weight after 60 Days of Cultivation}

According to variance analysis results, the pigweed control method has significant effect on its density in 60 days after cultivation in $1 \%$ probability level. In nitrate ammonium fertilizer, 
no significant difference was seen according to density among various control methods (Figure (11)); however, the pigweed dry weight in chemical and combined methods are $76 \%$ less than non-control method in this treatment. (Figure (12)). The highest density and dry weight of pigweed was obtained 56 bushes in $\mathrm{m}^{2}$ and $855 \mathrm{gr} / \mathrm{m}^{2}$ in non-control method and nitrate calcium fertilizer treatment and 53 bushes in $\mathrm{m}^{2}$ and $805 \mathrm{gr} / \mathrm{m}^{2}$ in urea fertilizer, respectively. According to pigweed dry weight, no significant difference was seen among chemical and combined control methods in all studied fertilizers. (Figure (12)) The results of the main effects comparison of control method and nitrogen fertilizer in table (2) and (3) show that the maximum pigweed density and dry weight in non-control treatment were obtained with 41.86 bushes in $\mathrm{m}^{2}$ and $640.16 \mathrm{gr} / \mathrm{m}^{2}$. The main effects of chemical and combined control methods didn't show significant difference on density and dry weight of pigweed (Table (2)). In addition, the nitrate calcium has thee maximum effect on increasing pigweed dry weight than other fertilizers.

\section{FRESH CORN FORAGE}

The variance analysis results of forage performance showed that the weed control methods, type of nitrogen fertilizers, and interaction of pigweed control method and type of nitrogen fertilizers showed significant effect on performance of fresh corn forage in $1 \%$ significance level.

The results of comparison the mean main effects of control method on forage performance are shown in table (2). Results showed that the best performance was obtained in combined control treatment. The results of mean main effects of nitrogen fertilizer types on performance also showed that the maximum performance in nitrate calcium treatment and nitrate ammonium was obtained $10927.86 \mathrm{~kg} / \mathrm{hec}$ and then no significant difference was seen among urea treatments and sulfate ammonium according to performance. In addition, the minimum performance was obtained with mean of $8264.16 \mathrm{~kg} / \mathrm{hec}$ in non-control treatment. (Table (3)).

The interaction of weed control methods and nitrogen fertilizers types on mean performance is shown in figure (13). According to results of mean comparison, the highest fresh corn forage performance was obtained in combined control treatment and nitrate calcium fertilizer 
with approximate mean of $12072 \mathrm{~kg} / \mathrm{hec}$ which was $46 \%$ more than the minimum performance in non-using fertilizer treatment. In all studied fertilizers in test except urea, performance in chemical and combined control methods wasn't different and the performance in chemical and combined control methods was significantly higher than non-control method; as though, performance in non-control treatment than two chemical and combined control methods in fertilizers (urea, nitrate calcium, nitrate ammonium, and without-fertilizer) was $29 \%, 15 \%, 39 \%, 46 \%$, and $15 \%$ less. The maximum performance difference among chemical and combined methods with non-control treatment in nitrate ammonium and nitrate calcium fertilizers were obtained with $39 \%$ and $46 \%$ difference. In Billow et al. study, the effect of four nitrogen resources including nitrate calcium, nitrate ammonium, urea, and combination of urea and nitrate ammonium in 4 surfaces on corn. According to results of this test, no performance difference was among four fertilizers (Below et al., 1995). In another study, effect of two urea-nitrate ammonium and ammonia resources without water was examined on corm. Results showed no significant statistical difference on effects of forage performance. (Barge, 2002) Heydari et al. (2011) studied three types of nitrogen feeding from nitrate, ammonium, and combination of nitrate and ammonium resources on growth and fleawort biochemical reaction. The obtained results of this study showed that the type of nitrogen type was significant only on proline. Its effect on chlorophyll and the leaves' solved hydrocarbons wasn’t significant.

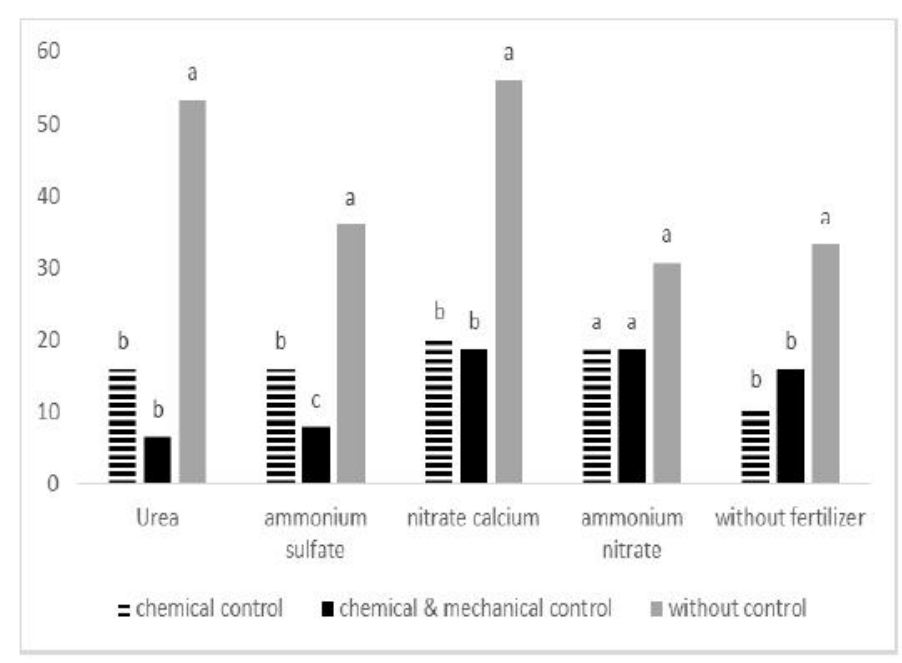

Fig.11. interaction of fertilizer type and control method on pigweed means density (bushes in $\mathrm{m}^{2}$ ) after 60 days of cultivation 


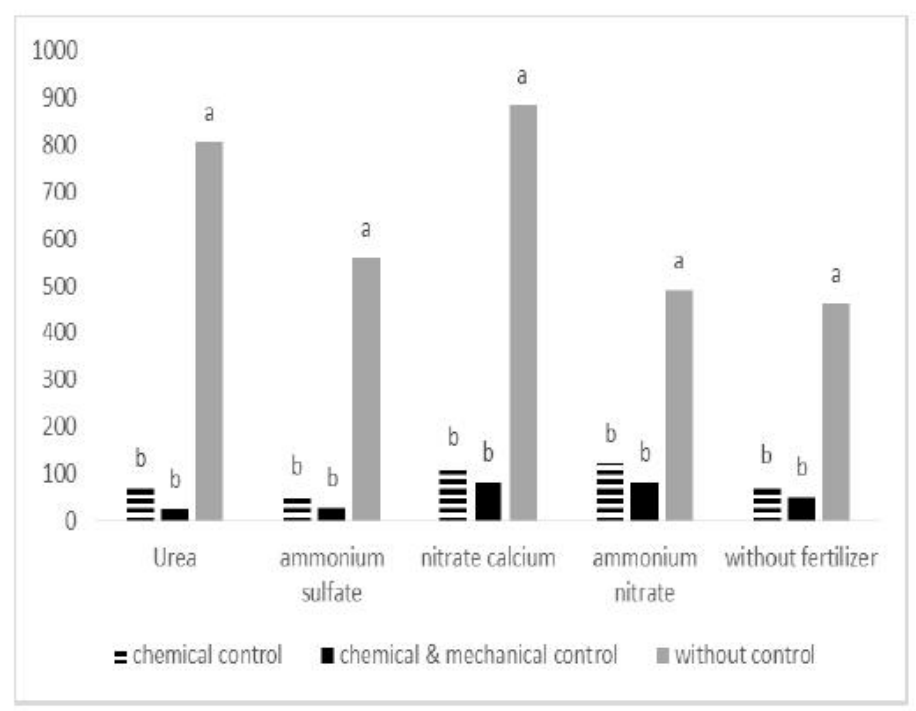

Fig.12. Interaction of fertilizer type and control method on pigweed means dry weight (bushes in $\mathrm{m}^{2}$ ) after 60 days of cultivation

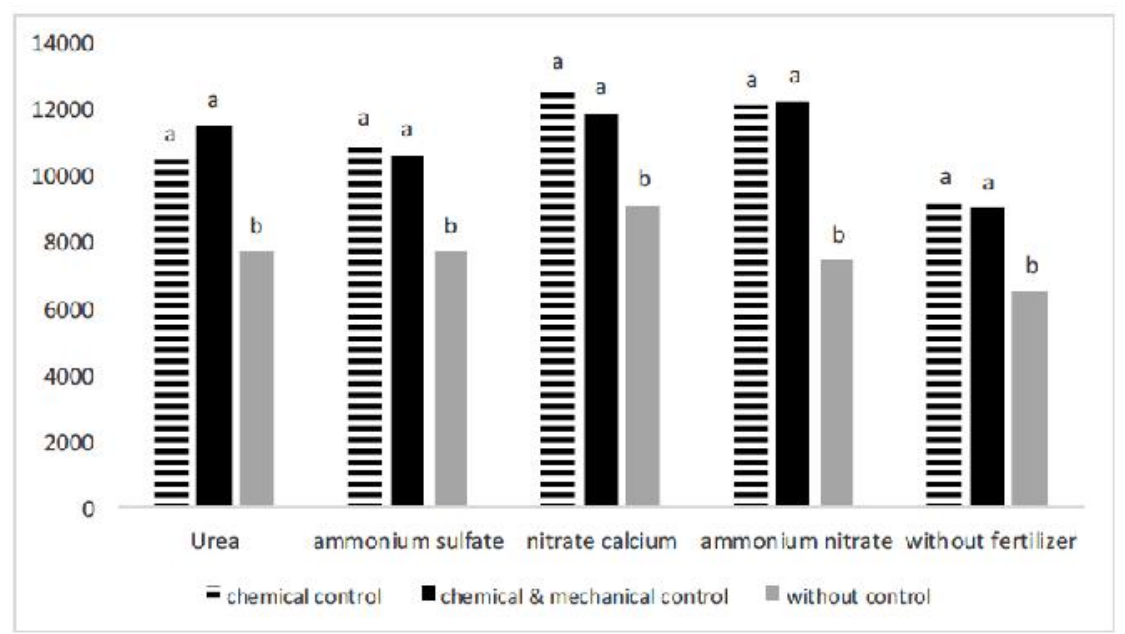

Fig.12. interaction of fertilizer type and control method on mean performance of fresh forage $(\mathrm{kg} / \mathrm{hec})$

Table 2. The main effect of pigweed control methods on the studied traits in test

\begin{tabular}{|c|c|c|c|c|c|}
\hline & \multicolumn{4}{|c|}{$\begin{array}{l}40 \text { days after cultivation } \\
\text { cultivation }\end{array}$} & 60 days after \\
\hline & $\begin{array}{l}\text { The } \\
\text { performance } \\
\text { of fresh } \\
\text { forage } \\
(\mathrm{kg} / \mathrm{hec})\end{array}$ & $\begin{array}{l}\text { Weed } \\
\text { density } \\
\text { (bushes } / \mathrm{m}^{2} \text { ) }\end{array}$ & $\begin{array}{l}\text { Pigweed dry } \\
\text { weight } \\
\left(\mathrm{gr} / \mathrm{m}^{2}\right)\end{array}$ & $\begin{array}{l}\text { Pigweed } \\
\text { density } \\
\text { (bushes } / \mathrm{m}^{2} \text { ) }\end{array}$ & $\begin{array}{l}\text { Fresh forage } \\
\text { performance } \\
(\mathrm{kg} / \mathrm{hec})\end{array}$ \\
\hline $\begin{array}{l}\text { Chemical } \\
\text { control }\end{array}$ & $11108.2 \mathrm{a}$ & $21.33 b$ & $101.86 b$ & $16.26 \mathrm{~b}$ & $86.1 \mathrm{~b}$ \\
\hline Chemical and & $11069.23 \mathrm{a}$ & $18.66 \mathrm{~b}$ & $58.56 \mathrm{~b}$ & $13.6 \mathrm{~b}$ & $51.55 \mathrm{~b}$ \\
\hline
\end{tabular}




\begin{tabular}{|l|l|l|l|l|l|}
\hline $\begin{array}{l}\text { mechanical } \\
\text { control }\end{array}$ & & & & & \\
\hline $\begin{array}{l}\text { Without } \\
\text { control }\end{array}$ & $7711.46 \mathrm{~b}$ & $51.73 \mathrm{a}$ & $335.44 \mathrm{a}$ & $41.86 \mathrm{a}$ & $640.16 \mathrm{a}$ \\
\hline
\end{tabular}

Mean values followed by the same letter do not differ between treatments as determined by Fisher's Protected LSD test at $\mathrm{P}=0.05$

Table 3. Main effects of nitrogen fertilizer resource on the studied traits in test

\begin{tabular}{|c|c|c|c|c|c|}
\hline & \multicolumn{4}{|c|}{$\begin{array}{l}40 \text { days after cultivation } \\
\text { cultivation }\end{array}$} & 60 days after \\
\hline & $\begin{array}{l}\text { The } \\
\text { performance } \\
\text { of fresh } \\
\text { forage } \\
(\mathrm{kg} / \mathrm{hec})\end{array}$ & $\begin{array}{l}\text { Weed } \\
\text { density } \\
\text { (bushes } / \mathrm{m}^{2} \text { ) }\end{array}$ & $\begin{array}{l}\text { Pigweed dry } \\
\text { weight } \\
\left(\mathrm{gr} / \mathrm{m}^{2}\right)\end{array}$ & $\begin{array}{l}\text { Pigweed } \\
\text { density } \\
\text { (bushes } / \mathrm{m}^{2} \text { ) }\end{array}$ & $\begin{array}{l}\text { Fresh forage } \\
\text { performance } \\
(\mathrm{kg} / \mathrm{hec})\end{array}$ \\
\hline Urea & $9908.27 b$ & $33.33 \mathrm{a}$ & $170.99 a$ & $25.33 \mathrm{ab}$ & $298.88 \mathrm{ab}$ \\
\hline $\begin{array}{l}\text { Ammonium } \\
\text { sulfate }\end{array}$ & $9786.66 b$ & $28.88 \mathrm{a}$ & $151.86 \mathrm{a}$ & $20 \mathrm{~b}$ & $212.14 \mathrm{~b}$ \\
\hline $\begin{array}{l}\text { Nitrate } \\
\text { calcium }\end{array}$ & $11239.22 \mathrm{a}$ & $31.55 \mathrm{a}$ & $161.51 \mathrm{a}$ & $31.55 \mathrm{a}$ & $359.72 \mathrm{a}$ \\
\hline $\begin{array}{l}\text { Ammonium } \\
\text { nitrate }\end{array}$ & $1061.5 \mathrm{ab}$ & $29.77 \mathrm{a}$ & $159.45 a$ & $22.66 a b$ & $230.88 b$ \\
\hline $\begin{array}{l}\text { Without } \\
\text { fertilizer }\end{array}$ & $8264.16 \mathrm{c}$ & $29.33 \mathrm{a}$ & $182.62 \mathrm{a}$ & $20 \mathrm{~b}$ & $194.74 \mathrm{~b}$ \\
\hline
\end{tabular}


Table 4. Variance analysis of the studied traits in test

\begin{tabular}{|c|c|c|c|c|c|c|}
\hline $\begin{array}{l}\text { Source of } \\
\text { variance }\end{array}$ & $\begin{array}{l}\text { Degree } \\
\text { of } \\
\text { freedom }\end{array}$ & $\begin{array}{l}\text { Fresh forage } \\
\text { performance }\end{array}$ & $\begin{array}{l}\text { Pigweed } \\
\text { density } \\
\text { after } 40 \\
\text { days of } \\
\text { cultivation } \\
\end{array}$ & $\begin{array}{l}\text { Pigweed } \\
\text { density } \\
\text { after } 60 \\
\text { days of } \\
\text { cultivation } \\
\end{array}$ & $\begin{array}{l}\text { Pigweed } \\
\text { dry weight } \\
\text { after } 40 \\
\text { days of } \\
\text { cultivation }\end{array}$ & $\begin{array}{l}\text { Pigweed } \\
\text { dry weight } \\
\text { after } 60 \\
\text { days of } \\
\text { cultivation }\end{array}$ \\
\hline \multicolumn{7}{|l|}{ Replication } \\
\hline \multicolumn{7}{|l|}{$\begin{array}{l}\text { Control } \\
\text { method }\end{array}$} \\
\hline \multicolumn{7}{|l|}{$\begin{array}{l}\text { Type of } \\
\text { nitrogen } \\
\text { fertilizer }\end{array}$} \\
\hline \multicolumn{7}{|l|}{$\begin{array}{l}\text { Type } \\
\text { nitrogen } \\
\text { fertilizer } \\
\text { control } \\
\text { method }\end{array}$} \\
\hline \multicolumn{7}{|l|}{ Error } \\
\hline $\begin{array}{l}\text { Coefficient of } \\
\text { variation }(\%)\end{array}$ & & & & & & \\
\hline
\end{tabular}

** Significance at $5 \%$ probability levels

Formulas and Mathematical Relations:

$\mathrm{F}=$ if $\left(\mathrm{X}<=0,0, \mathrm{a}^{*} \exp \left(-0.5^{*}(\ln (\mathrm{x} / \mathrm{x} 0) / \mathrm{b})^{\wedge} 2\right) / \mathrm{x}\right) \quad($ equation 1$)$

$\mathrm{F}=\mathrm{a} * \exp \left(-\mathrm{b}^{*} \mathrm{x}\right)($ equation 2$)$

In equation (1) and (2), $\mathrm{f}$ is pigweed density and dry weight in each time $\mathrm{x}$, a is the maximum value of the mentioned variable in growth season, and $b$ is equation coefficient. 


\section{DISCUSSION AND CONCLUSION}

According to the obtained results from test, it can be claimed that chemical control of pigweed in forage corn farm with Nicosulfuron has good efficiency and nearly similar weed control and forage performance was obtained for both chemical and combined control treatments. It may be possible that the lack of difference between these two methods is for competitiveness of weed plant that compensates the efficiency of chemical method than combined method.

Tet results about effect of the studied fertilizers on pigweed dry weight and density showed that pigweed dry weight is more influenced by type of fertilizer than its density and tis effect becomes more tangible gradually. The effect of type of fertilizer on wet forage performance was significant in $1 \%$. Stecker et al. stated that seed performance in corn was significantly influenced by nitrogen resources such as nitrate ammonium, urea, and nitrate ammonium+ ammonium thiosulfate, and nitrate ammonium showed better performance than urea nitrogen resources and urea (Stecker et al, 1993) Below et al. in a study tested the effect of four nitrogen fertilizer resources including nitrate calcium, nitrate ammonium, and combination of urea and nitrate ammonium in four levels on corn, and stated that there was no difference by seed performance in four types of fertilizers (Below et al, 1995).Swanton and Weis stated that the final result of competitiveness among weeds and agricultural plants and also nutrition absorbance depend on type and accessibility to resources. (Swanton and Weis, 1991).

It is suggested to study absorbing nitrogen fertilizers with different doses and resource in various agricultural plant growth steps.

\section{REFERENCES}

- Kuchaki, A., Zarif Ketabi, H., Nakhforush, A., 2001, ecological policies about weeds management, translation by Ferdowsi Mashhad publication.

- M.R., Jahad Akbar, R., Tabatabaei, H.R., Ebrahimian, 2004, study crisis period of control weed in Kabutarabad Esfahan. Sweat beet, vol. 20, No.1 
- Vafabakhsh, K., 1995. Study various control methods on weed competitiveness and elements performance of seed corn. M.Sc thesis of agriculture, agriculture faculty, Ferdowsi Mashhad University

- Vazin, F., 2006, the threshold competitiveness of Xanthium strumarium, agricultural sciences journal, 745-753, 13 (3)

- Kuchaki, A,M., Zarif Keetabi, H., Nakhforush, A., 1997, organic agriculture. Translation by Ferdowsi Mashhad University.

- Mousavi, M. R., 2001, combined management method principle for weed, first edition, Miaal publication, p: 468

- Zand, A., Baghestani Meybodi, M.A., Bitarafan, M., Shimi, P., 2007. The guidelines for the registered herbicides in Iran with weed resistance to herbicides approach, Mashhad University Jihad, p: 66

- Rashed Mohassel, M. H., Mousavi, S.K., translation, 2007, wed management principles. E.J., Aldrich, R.J., Kremer. Ferdowsi Mashhad Univeristy. M.J., Malakuti, Riyazi Hamedani, 1991, soil fertility and fertilizers. Academic publication center. P: 385

- Heydari, M., Abdollahzadeh, A., Farzaneh, F., 2011. Effects of various salinity levels and three types of nitogen feeding on biochemical reactions and growth of fleawort, agricultural plants sciences of Iran, 42. No.1, pp: 199-207

- Aguyoh, J. N., and J. B. Masiunas. 2003. Interference of redroot pigweed (Amaranthus retrofilexus) with snap beans. Weed Sci. 51: 202-207.

- Barge, G. L. 2002. Comparing source, rate and crop rotation effects on corn yield response to nitrogen on lake bed soils. Available from: http:// www. Ohioline. Osu. Edu/ Sc 190/pdf/ Sc 190, pdf, 22June 2008, 12.26

- PM.Extension Research Bulletin ,187.

- Below, F. E., P. S. Brandau, and J. A. Yockey. 1995. Sources and forms of nitrogen for optimum corn production. Available from: http://www. Frec. Crops. Uiuc. Edu/search. Html, 22 June 2008, 12.04 PM. Lliaiss Fertilizer Conference Proceedings

- Boswell, F. C., J. J. Meisinger, and W. L. Case. 1985. Production, marketing and use of nitrogen fertilizers. In 
- Fertilizer Technology and Use. 3 rd ed. SSSA Madison, WI. pp. 229-292.

- DiTomoso, J. M. 1995. Approaches for improving crop competitiveness through the manipulation of fertilization strategies. Weed Science. 43: 491-497.

- Evans, S. P., Knezvic, S. Z., J. L. Lindquist and Ch. A. Shapiro. 2003. Influence of nitrogen and duration of weed interference on corn growth and development. Weed Sci.51:546-553.

- Guo, P. G. and K. Al-Khatib. 2003. Temperature effects on germination and growth of redroot pigweed

- (Amaranthus retroflexus), Palmer amaranth (A. palmeri), and common waterhemp (A. rudis). Weed Sci. 51:

- $869-875$.

- Koocheki, A., and M. Nassiri. 2005. Effects of different input levels on weed seed bank in wheat fields of

- Mashhad. Iranian J. Agron. Res. 3: 89-102. (In Persian with English abstract).

- Kropff, M. J., L. A. P. Lotz and S. E. Weaver. 1993. Practical applications in modeling crop weed interaction. In:

- “Kropff, M.J. H.H. Vanlaar. (Eds). IRRI. Book Publisher.

- Lany, N. S., R. G. Stevense, R. E. Thornton, W. L. Pan, and S. Victory. 1999. Nutrient management guide:

- central Washington irrigated potatoes. Washington State University Cooperative Extension and U.S. Department of Agriculture.

- Mitich, L. W. 1997. Redroot pigweed (Amaranthus retroflexus). Weed Tech. 11: 199202.

- Nieto, J. H. and Staniforth, D. W. 1961. Corn-foxtail competition under various production conditions. Agron. J. 53: 1-5.

- Sensmen S.A. 2007. Herbicide Handbook. (9th ed). Weed Science Society of America, $458 \mathrm{p}$.

- Stecker, J. A., D. D. Buschholz, R. G. Hanson, N. C. Wollenhaup, and K. A. Mcvay. 1993. Broad cast nitrogen sources for no-till continuous corn and corn 
flowing soybean. Agronomy journal, 58: 893-894. Swanton, C.J. \& Weise S.F. 1991. Integrated Weed Management: The rational and approach. Weed Technology, 5, 657-663.

- Vengris, J., Colby, W. G., and Drake, M. 1955. Plant nutrient competition between weeds and corn. Agron. J.

- 47: 213-216.

- Walker, R. H., and Buchanan, G. A. 1982. Crop manipulations in integrated weed management systems. Weed

- Sci. 30: 17-24.

\section{How to cite this article:}

Aryan Mehr M, Ghanbari A. Ghorbani R. Nasiri Mahallati M. Khorasani R, Asadi G. Density and dry weight of pigweed by various weed control methods and various resources of nitrogen fertilizer in corn forage farm. J. Fundam. Appl. Sci., 2016, 8(3), 1204-1223. 